\title{
Welcome Prince George, but if only...
}

\section{Susan Quilliam}

Writer, Broadcaster, Consultant and Trainer, Cambridge, UK

\section{Correspondence to} Ms Susan Quilliam; susan@susanquilliam.com; http://www.susanquilliam.com

Received 29 July 2013 Accepted 29 July 2013
To cite: Quilliam S. J Fam Plann Reprod Health Care 2013;39:295-296.

\section{BACKGROUND}

Welcoming the birth of new life is surely at the heart of every Journal reader's professional role. So I hope I won't be accused of being populist (or monarchist, or indeed anti-monarchist) as I devote this issue's Consumer Correspondent column to the recent appearance of the British third-in-line to the throne. For while Prince George Alexander Louis is of royal blood, his arrival reflects the delights, concerns, hopes and fears of every baby ever born - and hence is of interest to us all.

\section{NORMAL BIRTH ... UNIQUE FUTURE}

The royal child's journey into the world was the one that every human child takes. While we know little of the medical details, we do know that his mother enjoyed a largely standard pregnancy, which hit a worrying blip in the first weeks, then may or may not have overshot its due date. We will likely never know whether birth was induced, though the royal protection squad is reported to have done a 'dry run' from Kensington Palace to St Mary's Hospital just a few hours before the for-real early-morning hospital dash, which might suggest active scheduling. The 11-hour labour was par for the course for a first-time mother, and the ensuing 36-hour post-delivery stay in hospital was also within normal limits.

After which, however, all normality evaporated. Few new babies have a press pack of $200+$ camped out on the doorstep for 24/7 BirthWatch. Few are claimed not only by the country where they were born but by 54 other nations who regard them as the future Head of the Commonwealth. Few greet the world with their destiny already decided: their education (probably Eton); their career (probably the Armed Forces); their entire life plan (probably - barring abdication and the dissolution of the monarchy 40 years of waiting in the wings followed by an awful lot of hearing the National Anthem played just for you). And no new babies at all have up to now had their arrival marked by the biggest-selling national newspaper renaming itself The Son, and Niagara Falls recolouring itself blue.

\section{GOOD PREGNANCY PRACTICE}

Despite the unrepresentative future of the main character, I'm delighted to say that the royal birth itself has sent some very useful messages about good reproductive and parenting practice. Mum and Dad obviously planned their family. It is reported that despite any pressure to hastily produce the classic 'heir and a spare', Prince William made a strong stand against the speedy conception his own parents and grandparents had, and successfully argued for taking 18 months post-wedding to adjust to married life, and in Catherine's case, adjust to royal duties.

The Princess's own strong commitment to health leading up to and during her pregnancy - she is rumoured to have made the ultimate sacrifice and foresworn pizza - may have filled too many feature pages for everyone's liking, but it has certainly helped publicise the importance of good diet, exercise and lifestyle to fertility, conception and gestation. And her first-trimester illness, worrying though it was, allowed useful information on hyperemesis gravidarum to be disseminated nationwide and, arguably, worldwide.

Equally, though it is now many decades since fathers were banned from the delivery room - Prince Philip apparently played squash while the Queen was in labour with Prince Charles - it also sets a positive precedent that William was present at his son's birth and, likely, at the preceding antenatal classes. The excellent timing of the baby's arrival to coincide with the end of William's current career contract, and hence his 
ability to move to a more home-based post, further reinforces the essential role fathers play in family life.

\section{GOOD PARENTING PRACTICE}

Which leads us neatly from reproduction to rearing. The royal couple's approach is clearly that best parenting is not about privilege but about love; the royal baby will have every advantage that money and status can provide, but his parents' chief aim will be to give him the advantages delivered by consistent affection, acceptance and support. The Prince and Princess's priorities were made overt when they took the step unusual for royalty - of delaying public announcement of the birth for several hours, and outside visits for a whole day. One suspects that creating such a window of private opportunity for parent-child bonding is the initial marker that in the Cambridge family, relationships come first. Their stated intention is also to avoid the traditional royal assistance of a squad of full-time Norwood nannies in favour of 'hands-on' parenting and grandparenting.

Yes, William and Catherine are responsible for the upbringing of a future king with all the necessary inculcation of duty and commitment the new heir needs. But they are also responsible for the development of a human being and will surely aim first and foremost for the young prince to be psychologically mature and socially competent. And, judging by the couple's enthusiastic and effective interaction with youngsters during royal visits since their wedding, we may expect that to involve lots of cuddles; as the new baby's late grandmother once remarked "Hugging has no harmful side effects".

\section{TOO MUCH PERFECTION?}

All that said, I do have my concerns - not about the protagonists of this drama, but about the way those protagonists' story has been displayed on the world stage. The media coverage has been comprehensive as well as all-consuming but it has nevertheless missed an opportunity. For presenting the event as perfect, airbrushed and Photoshopped to within an inch of its life has meant failure to give crucial messages about the reality of new parenthood.

I'm in no way denying - nor I hope undermining the positivity that we should feel at the birth of a baby. Nor am I suggesting that just because this baby is royal we should celebrate any less positively. But hardly anywhere in what we have read, seen or heard about the birth has there been any analysis of the challenges of having a child, especially a first child.

So British Prime Minister David Cameron's comments that the first months of parenthood are "wonderful and magical"" were rarely balanced out with the phrases "physically exhausting", "emotionally draining" and "likely to have you frayed beyond measure". And few commentators felt able to qualify the global euphoria with the caveat that once that euphoria has died down, having a new baby can trigger a certain dark night of the soul at taking on the huge responsibility of a tiny new life.

Prince William's first-interview comment that his son "has a good pair of lungs on him" hinted at the broken sleep that the couple may have had the night before, but few people pointed out that those same disturbed nights, if repeated for the next several months or even years, can leave the most loving parents suffering critical sleep deprivation. Equally, the couple's love for each other is self-evidently unshakeable, so no one dared to mention that all new parents need to accommodate the adjustment of such love to include a third person, to accommodate a new way of life with a different division of labour. (Add in the postnatal depression from which so many mothers - and sometimes fathers - suffer and the task can seem overwhelming.)

\section{GETTING REAL}

I'm not alone in being wary of such media idealism. When OK Magazine seemed to suggest that Princess Catherine should embark on a post-pregnancy regime of diet and exercise, the Internet exploded with fury from parents worldwide, standing up for 'real' mothers who don't spring back into shape within days of labour. And when influential website Mumsnet asked for sound life advice to offer the Duke and Duchess, helpfully adding that "the early hours and days of [parenthood] are a mixture of elation, exhaustion [but also] trepidation", they received so many confirmatory tweets that an entire book will now be based around realistic guidance from the Mumsnet tribe.

I'm not suggesting for a moment that the royal parents won't cope. They will. The problem is that if coping is in any way a struggle for them, we won't hear about that for fear of spoiling the fairy tale. And, as we don't hear about it, those large numbers of other new parents who struggle may be left feeling deskilled, invalidated and lacking. And that in turn will make even harder the task of those who, as we Journal readers do, care for and support couples who embark on this most important life task.

I'm not being negative. I too whooped with joy and shed a happy tear when Prince George arrived, his tiny hands already giving a miniature royal wave.

It's just a shame that his arrival hasn't created the opportunity to send the following message: Adjusting to parenthood is not all unalloyed ecstasy, and parents who find it otherwise are not heartless nor hopeless, but simply human.

Competing interests None.

Provenance and peer review Commissioned; internally peer reviewed. 